\title{
PREVALENSI, KARAKTERISTIK, DAN PENANGANAN DELAYED ONSET MUSCLE SORENESS (DOMS)
}

\author{
Yanuar Prihantoro ${ }^{1}$, Rachmah Laksmi Ambardini ${ }^{1}$ \\ ${ }^{1}$ Fakultas Ilmu Keolahragaan, Universitas Negeri Yogyakarta, Jl. Colombo No. 1, Karangmalang, Depok, Sleman, \\ Daerah Istimewa Yogyakarta, Indonesia \\ yanuar560fik@ student.uny.ac.id, rachmah_la@uny.ac.id
}

\begin{abstract}
Abstrak
Latihan yang melibatkan kontraksi eccentric seringkali menimbulkan nyeri 1 hari setelah latihan (DOMS). Sampai saat ini prevalensi, karakteristik dan penanganan DOMS belum diketahui. Tujuan penelitian ini untuk mengetahui prevalensi, karakteristik, dan penanganan Delayed Onset Muscle Soreness (DOMS) anggota UKM olahraga di UNY. Penelitian ini merupakan penelitian deskriptif dengan menggunakan metode survei. Populasi penelitian ini adalah 150 orang dari 5 UKM olahraga UNY. Teknik sampling yang digunakan adalah aksidental sampling. Jumlah sampel adalah 60 orang. Instrumen penelitian yang digunakan adalah menggunakan angket. Analisis data yang digunakan adalah statistik deskriptif. Hasil penelitian diperoleh bahwa seluruh anggota UKM bidang olahraga UNY pernah mengalami DOMS. Penanganan yang dilakukan adalah stretching sebanyak $45 \%$ dan istirahat sebanyak $42 \%$. Penanganan yang dilakukan dirasa sudah efektif dalam mengurangi rasa nyeri akibat DOMS. Bagian yang sering mengalami DOMS adalah bagian betis (gastrocnemius) sebanyak $36 \%$ dan otot hamstring sebanyak $28 \%$.
\end{abstract}

Kata kunci: prevalensi, karakteristik, penanganan, nyeri, DOMS

\section{PREVALENCE, CHARACTERISTICS, AND HANDLING DELAYED ONSET MUSCLE SORENESS (DOMS)}

\begin{abstract}
Exercises that involve eccentric contractions often cause pain 1 day after exercise (DOMS). Until now, the prevalence, characteristics and handling of DOMS is unknown. The purpose of this study was to determine the prevalence, characteristics, and handling of Delayed Onset Muscle Soreness (DOMS) of UKM sports members at UNY. This research is a descriptive study using a survey method. The population of this study was 150 people from 5 UNY sports UKM. The sampling technique used was accidental sampling. The number of samples is 60 people. The research instrument used was using a questionnaire. Analysis of the data used is descriptive statistics. The results showed that all members of UKM in the UNY sports field had experienced DOMS. Handling is done by stretching as much as $45 \%$ and as much as $42 \%$ rest. Handling is considered effective in reducing pain due to DOMS. The part that often experiences DOMS is the calf (gastrocnemius) as much as $36 \%$ and hamstring muscles as much as $28 \%$.
\end{abstract}

Keywords: prevalence, characteristics, treatment, pain, DOMS

\section{PENDAHULUAN}

Delayed Onset Muscle Soreness (DOMS) adalah nyeri otot dan kekakuan yang berkembang selama 24-72 jam setelah melakukan aktivitas olahraga (Zondi et al. 2015). DOMS adalah pengalaman yang dirasakan oleh kalangan atlet elite atau alet pemula yang telah lama tidak melakukan aktivitas olahraga. DOMS dapat diartikan sebagai jenis kerusakan otot akibat olahraga, namun berbeda dengan keletihan otot atau nyeri yang berkembang sesaat atau segera setelah melakukan aktivitas olahraga. Menurut penelitian yang dilakukan oleh Contro et 
al. 2016 mekanisme terjadinya DOMS yang dialami seseorang disebabkan oleh latihan yang bersifat eccentric. Latihan eccentric merupakan latihan yang membutuhkan kontraksi otot yang memanjang dan memendek secara kuat. Hal ini ditunjukkan dengan sejumlah penelitian yang telah menguji tentang hubungan antara nyeri otot dan berbagai jenis latihan seperti latihan eccentric, concentric, dan aktivitas statis (Contro et al. 2016). Berbagai teori tentang DOMS menunjukkan bahwa DOMS merupakan penumpukan asam laktat, kejang otot, kerusakan jaringan ikat, kerusakan otot mekanis, inflamasi seluler, dan enzim (Contro et al. 2016). Berdasarkan berbagai penyebab tersebut DOMS dapat disebabkan oleh gabungan atau kombinasi dari mekanisme terjadinya DOMS yang ada.

DOMS dapat menyebabkan rasa sakit dan keterbatasan fungsional yang berdampak buruk pada performa seseorang dalam melakukan aktivitas olahraga. Nyeri pada DOMS hanya berlangsung selama 48-72 jam, bersifat ringan sampai sedang. DOMS dapat sembuh dengan sendiri, tetapi membutuhkan waktu sehingga DOMS dapat mengganggu program latihan, aktivitas sehari-hari, dan atlet yang akan bertanding. Pengetahuan tentang DOMS harus dimiliki oleh atlet elite maupun atlet pemula tentang penanganan terhadap atlet yang mengalami DOMS. DOMS dapat mempengaruhi penampilan seorang atlet karena rasa nyeri yang dirasakan sehingga berpotensi mengganggu program latihan yang akan dijalankan. DOMS memerlukan penanganan khusus untuk memperpendek durasi DOMS dan menurunkan intensitas nyeri yang dirasakan. Penanganan yang dilakukan agar program latihan tetap berjalan dengan tujuan yang akan dicapai.

Resiko terjadinya DOMS dapat dikurangi dengan memberikan berbagai penanganan seperti stretching, minum obat NSAID (Non Steroid Anti Inflamatory Drug), kompres es, kompres hangat, masase, istirahat, dan tetap melakukan latihan. Penanganan yang dilakukan oleh setiap orang berbeda-beda disesuaikan dengan kondisi dan kebutuhan yang dialami oleh seseorang. Menurut Rensburg et al. 2015 pemberian masase dan menggunakan NSAID dapat mengurangi rasa nyeri DOMS. Masase yang diberikan segera setelah berolahraga berat dapat mengurangi rasa sakit yang disebabkan oleh DOMS. Disamping menggunakan masase penanganan DOMS dapat menggunakan obat NSAID yang diminum setelah melakukan aktivitas olahraga. Penggunaan NSAID bergantung pada dosis dan waktu penggunaan setelah melakukan aktivitas olahraga. NSAID bekerja dengan menghambat gejala dari DOMS yaitu rasa nyeri yang berat setelah melakukan aktivitas olahraga berat. NSAID tidak memiliki dampak negatif terhadap pertumbuhan otot, namun harus digunakan sesuai dengan aturan.

\section{Patofisiologi DOMS}

Proses terjadinya DOMS dapat dihubungkan dengan pembentukan asam laktat dalam otot pasca olahraga yang rutin dilakukan namun sekarang terbukti bahwa pendapat tersebut tidak berhubungan langsung dengan kejadian DOMS. DOMS sering ditimbulkan oleh gerakan eccentric. Berbagai jenis olahraga yang menyebabkan deformitas membran otot sehingga akan diawali terjadinya respon inflamasi yang menyebabkan pembentukan produk-produk sampah metabolik, untuk berperan sebagai stimulus kimiawi kepada ujung saraf. Kontraksi eccentric terjadi saat otot yang aktif sedang memanjang tersebut dapat berhubungan dengan adanya peningkatan yang terlambat pada tingkat serum dari enzim spesifik otot seperti creatin kinase (CK) sehingga memicu kerusakan serabut otot (Jones et al. 1989). Olahraga yang menyebabkan kerusakan otot/exercise induced muscle damage, dapat dihubungkan dengan adanya inflamasi aceptic yang didukung beberapa bukti bahwa permukaan otot mengalami nyeri dan bengkak. DOMS sering ditimbulkan terutama oleh latihan eccentric seperti lari menuruni bukit atau downhill running, plyometrics, dan latihan dengan tahanan. Pada dasarnya setiap gerakan yang tidak biasa dilakukan akan menimbulkan nyeri otot, khususnya gerakan yang membuat otot berkontraksi memanjang. Contoh latihan beban yang menyebabkan kontraksi otot yang seperti ini antara lain naik-turun tangga, jogging, menurunkan berat badan (seperti pada latihan bicep 
curl), squat, dan push-up. Berbagai latihan ini menyebabkan kerusakan pada sel membran otot sehingga akan memulai terjadinya respon inflamasi menyebabkan kerusakan pada sel membran otot sehingga akan memulai terjadinya respon inflamasi sehingga menyebabkan pembentukan produk-produk sampah metabolik yang berperan sebagai stimulus kimiawi kepada ujung saraf atau nerve endings. Pada saat melakukan kontraksi eccentric dan consentric otot beradaptasi untuk memanjang dan memendek. Pada kontraksi eccentric otot berada pada kontraksi yang optimal memanjang sehingga dapat menimbulkan ketidakstabilan dari otot terutama terjadi pada sarkomer yang berada pada posisi memanjang. Jika sarkomer pada kontraksi memanjang dan pada tegangan yang optimal maka kemungkinan terjadi kerusakan jaringan otot dapat terjadi (Proske \& Morgan, 2001: 23).

DOMS selalu dikaitkan dengan keadaan yang tidak biasa, kerja otot yang berlebihan dan kontraksi eccentric dapat memicu terjadinya DOMS. Kontraksi otot eccentric dapat dilihat dari adanya perpanjangan otot selama otot berkontraksi. Muscle soreness terjadi ketika serabut otot mengalami robekan, dan otot beradaptasi untuk menjaga kekuatannya. Muscle strain terjadi karena akibat latihan berlebih yang terjadi pada sebagian besar serabut otot yang berpengaruh terhadap derajat gerak dan tendon (Connoly et al, 2003). Tingkat kerusakan dan nyeri dapat disebabkan beberapa faktor misalnya pada tingkat keterlatihan disebabkan oleh dosis latihan dan intensitas dari latihan yang diberikan. Pada beberapa kasus yang terjadi, kerusakan dapat disebabkan karena aktivitas otot melebihi dari kemampuan dalam melakukan aktivitas dan gerakan yang salah. Faktor yang lain adalah kekakuan otot, kecepatan kontraksi, kelelahan otot, dan sudut pada saat akan melakukan gerakan. DOMS dapat diklasifikasikan sebagai cedera pada otot tipe I dan dapat diketahui dengan adanya nyeri tekan dan kejang otot pada saat dilakukan palpasi dan gerakan. Nyeri tekan dapat terlokalisasi pada bagian distal otot dan dapat bertambah nyeri dalam waktu 24-48 jam setelah melakukan latihan. Rasa nyeri tersebut dapat menggambarkan tingginya reseptor pada jaringan lunak dan pada tendon otot (Cheung et al, 2003).

DOMS dapat terjadi karena nyeri otot yang disebabkan oleh kerusakan jaringan otot. Pada pemeriksaan biopsi, kerusakan otot yang terjadi pada sarkolema yang pecah memungkinkan isi sel meresap antara serat otot lainnya. Kerusakan filamen kontraktil aktin dan miosin serta kerusakan $Z$ line merupakan bagian dari terjadinya kerusakan struktural sel. Terjadinya respon inflamasi merupakan respon terhadap cedera pada sistem kekebalan tubuh. Kerusakan struktural akut pada jaringan otot dapat memulai terjadinya DOMS dan dapat mengarah terjadinya nekrosis memuncak sekitar 48 jam setelah latihan. Isi intraseluler dan efek respon imun kemudian terakumulasi di luar sel, merangsang ujung saraf dari otot (Merquez et al., 2001).

Melakukan latihan tidak terprogram yang melibatkan kontraksi otot eccentric dapat menyebabkan terjadinya cedera karena pemberian latihan yang berulang-ulang. Jika latihan yang dilakukan secara berlebihan maka akan menimbulkan cedera pada otot dan menyebabkan terjadinya kerusakan otot karena efek latihan yang berat. Latihan yang tidak dikontrol dengan baik tersebut dapat menyebabkan timbulnya kerusakan otot, peradangan, nyeri dan menurunnya ruang gerak sendi. Karakteristik lesi mikroskopik meluas dan akan terjadi kerusakan total miofibril pada Z-line, dan akan meluas pada kerusakan sarkomer. Ini merupakan salah satu penyebab ketegangan atau nyeri pada semua area otot yang akan mengurangi keterlibatan motor unit pada saat kontraksi eccentric. Nosiseptor pada jaringan ikat di daerah arteri, kapiler, dan struktur jaringan otot dan tendon akan terjadi nyeri. (Cheung et al., 2003).

Pencegahan dan Penanganan DOMS Pencegahan dan penanganan DOMS dapat dilakukan dengan beberapa cara yang dapat dilakukan saat mengalami nyeri yang dirasakan setelah berlatih. Beberapa cara untuk mencegah dan menangani DOMS: 1) Stretching/Penguluran. Penguluran yang dilakukan setelah melakukan latihan dapat 
mengurangi resiko terjadinya DOMS pada seorang atlet. Penguluran dapat berupa PNF stretching pada otot-otot besar pada tungkai seperti otot hamstring, quadriceps femoris, dan gastrocnemius. Otot besar yang mengalami DOMS dapat berkurang rasa nyeri yang dirasakan setelah dilakukan penguluran. Otot yang sudah dilakukan penguluran menjadi lebih elastis dan meningkat kelenturannya. Proprioceptive Neuromuscular Facilitation (PNF) adalah teknik peregangan yang umum digunakan dalam lingkungan atletik dan klinis untuk meningkatkan baik aktif dan berbagai pasif gerak (ROM) dengan maksud untuk mengoptimalkan performa motor dan rehabilitasi. Latihan PNF sangat efektif digunakan untuk meningkatkan ROM, khususnya dengan perubahan jangka pendek ROM (Melanie J, dkk, 2006:930). Kayla B, dkk (2012: 105) mengatakan bahwa Proprioceptive Neuromuscular Facilitation (PNF) adalah teknik peregangan yang dimanfaatkan untuk meningkatkan elastisitas otot dan telah terbukti memiliki efek positif pada kisaran aktif dan pasif gerakan. Elastisitas otot yang baik dapat mengurangi rasa nyeri yang disebabkan oleh DOMS setelah berlatih., 2) Masase/Pijat. Masase/pijat dapat mengurangi rasa sakit yang disebabkan oleh DOMS yakni dengan memperlancar peredaran darah pada bagian yang mengalami rasa nyeri akibat DOMS. Masase yang diberikan hanya memberikan efflurage dan shaking pada bagian yang mengalami rasa nyeri akibat DOMS. Manipulasi yang dilakukan dapat membantu memperlancar aliran darah pada otot yang mengalami rasa nyeri akibat DOMS. Masase yang diberikan segera setelah berolahraga dapat mengurangi jumlah rasa sakit dan kekakuan yang dirasakan setelah berolahraga. Meskipun ada peningkatan gejala analgesik yang dirasakan tetapi masase tidak berpengaruh pada fungsi otot dan enzim yang disebabkan oleh kerusakan sel atau inflamasi (Rensburg et al. 2015). Pemberian masase yang tepat dapat mengurangi rasa sakit yang disebabkan oleh DOMS., 3) Istirahat. Salah satu cara untuk mengurangi rasa sakit yang disebabkan oleh DOMS adalah dengan melakukan istirahat total setelah terasa nyeri setelah berolahraga. Melalui istirahat yang dilakukan selama \pm 5 hari dapat mengurangi rasa sakit yang ditimbulkan oleh DOMS. Istirahat yang dilakukan dengan tidak melakukan aktivitas olahraga termasuk penguluran sehingga otot beristirahat. DOMS biasanya hanya terasa selama 24-72 jam setelah berlatih (Rensburg et al. 2015). Berdasarkan lamanya terasa DOMS dapat diketahui istirahat dapat mengurangi rasa sakit yang ditimbulkan oleh DOMS setelah melakukan latihan secara berat., 4) Kompres Es. Pemberian kompres es merupakan salah satu sarana untuk mengurangi adanya peradangan pada bagian otot tertentu setelah melakukan aktivitas berat. Kompres es yang diberikan setelah melakukan latihan dapat mengurangi adanya rasa sakit setelah melakukan latihan. Mekanisme pengurangan rasa nyeri akibat DOMS dapat ditunjukkan yakni pemberian es yang dapat mempersempit pembuluh darah dan mempercepat proses pemulihan dengan mengurangi peradangan yang terjadi pada otot yang bekerja terlalu berat.

Kraemer et al. 2014 melakukan penelitian terhadap 50 orang yang diambil repetisi maksimal (RM) dalam latihan beban. Setelah melakukan pengambilan repetisi maksimal orang coba mengalami rasa nyeri yang parah. Kemudian orang coba diberikan perlakuan kompres es pada bagian yang mengalami DOMS. Hasil menunjukkan bahwa kompres es dapat mengurangi pembengkakan dan mempercepat pemulihan setelah aktivitas olahraga yang berat. Hal di atas menunjukkan bahwa kompres es dapat mengurangi rasa nyeri akibat DOMS.

Latihan olahraga yang dilakukan secara rutin dan teratur dapat membentuk tubuh dan sistem organ tubuh menjadi lebih baik serta menjadikan tubuh menjadi lebih bugar. Latihan yang dilakukan dengan program yang salah atau dilakukan secara tidak teratur dapat menimbulkan berbagai permasalahan seperti cedera dan hasil yang tidak maksimal. Latihan yang melibatkan kontraksi kontraksi eccentric yang membutuhkan kerja otot memanjang. Aktivitas fisik yang biasa memicu untuk melakukan kontraksi otot eccentric seperti latihan beban, lari cepat, lari mendaki bukit, lari cepat, dan naik turun tangga. Otot yang dominan melakukan kontraksi eccentric akan lebih mudah mengalami kelelahan dan timbul rasa nyeri 
setelah melakukan aktivitas. Latihan yang dilakukan dapat memicu timbulnya asam laktat pada otot yang digunakan untuk berkontraksi. Asam laktat yang menumpuk mengganggu performa dan menimbulkan rasa nyeri saat digunakan beraktivitas. Kontraksi yang berlebihan dan banyaknya asam laktat yang menumpuk tidak lepas dari program latihan yang diberikan pelatih. Program yang salah lebih cepat memicu timbulnya rasa nyeri yang disebabkan oleh asam laktat dan kontraksi otot yang berlebihan.

Ketegangan otot yang berlebih dan asam laktat memicu terjadinya respon inflamasi atau peradangan otot yang menimbulkan rasa nyeri setelah melakukan latihan. Respon inflamasi yang ditimbulkan memicu timbulnya nyeri setelah melakukan latihan. Gangguan yang terjadi akibat kontraksi eccentric, asam laktat, dan program latihan menyebabkan rasa nyeri. Rasa nyeri yang dirasakan sesaat setelah melakukan latihan dapat dikatakan sebagai delayed onset muscle soreness (DOMS).

Delayed onset muscle soreness (DOMS) merupakan gangguan berupa pegal otot yang terjadi akibat latihan yang tidak lazim yang disebabkan oleh respon inflamasi. DOMS sering dialami oleh semua individu yang melakukan aktivitas fisik terlalu berat setalah lama tidak beraktivitas. DOMS dapat dialami oleh setiap orang yang melakukan aktivitas olahraga yang tidak rutin. Nyeri yang dirasakan pada DOMS berlangsung dalam rentang waktu 48-72 jam setelah melakukan latihan. Nyeri yang dirasakan saat mengalami DOMS bersifat ringan sampai sedang tidak sampai ke nyeri yang berat. DOMS dapat sembuh dengan sendiri, namun membutuhkan waktu yang cukup lama. Waktu yang dibutuhkan untuk menyembuhkan DOMS dapat menggangu program latihan, aktivitas sehari-hari, dan bahkan saat pertandingan DOMS dapat muncul. DOMS yang dialami jarang dirasakan karena DOMS merupakan akibat dari latihan yang lama tidak dilakukan. DOMS dapat segera hilang juga dibantu tubuh dengan adaptasi yang dilakukan oleh tubuh yang terbiasa dengan gerakan atau olahraga yang dilakukan. Lokasi terjadinya DOMS dapat dipicu dengan dominan bagian tubuh yang digunakan dalam suatu cabang olahraga. Semakin banyak digunakan semakin besar resiko terkena DOMS. Tanda dan gejala yang dirasakan seperti kaku otot, lebam, bengkak, dan penurunan ruang gerak sendi.

DOMS yang dirasakan dapat dikurangi dengan memberikan berbagai penanganan. Penanganan yang dilakukan dapat berupa stretching, minum obat, istirahat, masase, terapi es, dan tetap melakukan latihan meskipun nyeri. Stretching yang dilakukan dapat mengurangi rasa nyeri yang dirasakan karena otot mengalami penguluran dan dilepaskan kembali sehingga kontraksi berkurang setelah melakukan stretching, namun stretching tidak terlalu efektif dalam mengurangi rasa nyeri akibat DOMS. Istirahat salah satu penanganan terhadap nyeri DOMS yakni dengan membiarkan bagian yang mengalami DOMS beristirahat. Aktivitas yang biasa dilakukan dikurangi untuk menghindari terjadinya DOMS. Penanganan yang dapat dilakukan seperti memberikan masase/pijat pada bagian yang mengalami DOMS. Masase yang diberikan dapat merangsang sistem saraf tepi dan memperlancar peredaran darah yang terhambat pada bagian yang mengalami DOMS. Masase diberikan pada bagian otot yang mengalami rasa nyeri akibat DOMS agar peredaran darah kembali normal. Penanganan menggunakan kompres es merupakan salah satu konsep untuk mengurangi respon inflamasi dengan mempersempit pembuluh darah dengan es. Kompres es yang diberikan dapat menyebabkan penyempitan pembuluh darah (vasokonstriksi) pada bagian yang mengalami DOMS. Penyempitan ini menyebabkan rasa nyeri yang dirasakan dapat berkurang.

Berdasarkan pemikiran tersebut dapat diketahui bahwa DOMS berawal dari kontraksi eccentric, asam laktat, dan program latihan. kontraksi eccentric, asam laktat, dan program latihan memicu kerusakan membran sel otot, kemudian timbul respon inflamasi. Respon inflamasi yang dirasakan memicu terjadinya DOMS. DOMS dapat hilang sendiri, namun perlu ditangani dengan benar agar tidak mengganggu program latihan, aktivitas sehari-hari, dan performa selama bertanding. Berbagai gejala yang dirasakan dapat memicu tanda gejala DOMS 
seperti nyeri, spasme otot, bengkak, dan penurunan ruang gerak sendi. Gejala DOMS yang dirasakan dapat dikurangi dengan stretching, istirahat, masase, dan kompres es.

\section{METODE}

Penelitian ini merupakan penelitian deskriptif dengan menggunakan metode survei, adapun teknik pengumpulan data menggunakan angket. Penelitian deskriptif merupakan penelitian yang digunakan untuk mengumpulkan informasi mengenai status suatu gejala, dimana gejala keadaan menurut apa adanya pada saat penelitian dilakukan (Suharsini Arikunto, 1996: 309).

Penelitian ini menggunakan metode survei dengan menggunakan angket/kuisioner yang diadakan untuk memperoleh fakta-fakta dari gejala yang ada dan mencari keterangan secara faktual dari suatu kelompok atau suatu daerah. Penelitian ini menggunakan pendekatan cross sectional, yaitu dengan cara pengumpulan data sekaligus pada suatu dengan tujuan untuk mengetahui prevalensi dan penanganan DOMS anggota UKM olahraga UNY. Penelitian dilakukan di seluruh anggota Unit Kegiatan Mahasiswa (UKM) olahraga Universitas Negeri Yogyakarta dengan cara memberikan angket kepada responden untuk mendapatkan data yang diperlukan.

Dari populasi yang ada diambil 60 anggota UKM olahraga UNY yang mengembalikan angket yang diberikan oleh penulis. 60 anggota yang mengembalikan angket dijadikan sebagai sampel. Maka sampel yang digunakan sebanyak 60 anggota UKM bidang olahraga UNY. Teknik pengumpulan data dalam penelitian ini adalah dengan teknik angket. Teknik angket ini digunakan untuk mengetahui prevalensi penanganan DOMS anggota UKM olahraga UNY.

\section{Teknik Analisis Data}

Teknik analisis data dalam penelitian ini menggunakan perhitungan statistik deskriptif. Menurut Pangestu Subagyo (1998: 65), statistik deskriptif adalah bagian dari statistik yang berfungsi untuk mengumpulkan data, menentukan nilai-nilai statistik, dan membuat diagram atau grafik mengenai suatu hal agar mudah dibaca dan dipahami. Data yang didapat dari 10 pertanyaan angket, diberi nilai untuk setiap butir pertanyaan. Dalam setiap butir disediakan jawaban yang bervariasi untuk mendaptakan hasil yang diinginkan. Pertanyaan yang diberikan berdasarkan keadaan yang sering terjadi dalam kehidupan dan pengalaman dari penulis. Data yang diperoleh akan menunjukkan keadaan dan penanganan yang sudah dilakukan selama mengalami DOMS.

\section{HASIL DAN PEMBAHASAN}

Penelitian dilakukan untuk mengetahui prevalensi penanganan DOMS anggota UKM bidang olahraga UNY. Data penelitian diperoleh dengan memberikan kuesioner kepada responden tentang penanganan DOMS yang pernah dialami. Hasil analisis data diketahui bahwa mayoritas usia anggota UKM bidang olahraga UNY pada rentang 19-20 tahun yaitu sebanyak 68\% dari keseluruhan responden. Dalam hal ini rentang usia ini merupakan usia untuk mahasiswa baru yang sedang semangat mengikuti kegiatan di UKM untuk mencari pengalaman dan jatidiri, namun masih ada anggota yang berusia tua yang biasanya dijadikan sebagai senior di UKM yakni sebanyak $2 \%$ dari keseluruhan responden.

Berdasarkan tinggi badan diketahui mayoritas responden memiliki tinggi $161-170 \mathrm{~cm}$ yang merupakan rentang tinggi badan untuk laki-laki. Tinggi badan 161-170 cm berjumlah 47\% dari keseluruhan responden. Tinggi badan ini paling banyak dimiliki oleh laki-laki. Berdasarkan berat badan sebagian besar anggota berada pada kisaran 51-70 kg yang merupakan berat badan ideal sesuai dengan tinggi badan yang dimiliki. Anggota dengan berat badan 51$70 \mathrm{~kg}$ sebanyak $67 \%$ dari keseluruhan responden. Berat badan tersebut berimbang dengan ratarata tinggi badan mayoritas responden. 
Berdasarkan jenis kelamin diketahui mayoritas reponden adalah laki-laki yakni sebesar 68\% dari keseluruhan responden. Laki-laki memang identik dengan olahraga yang menyebabkan mayoritas peminat olahraga adalah laki-laki meskipun tetap ada wanita yang meminati olahraga. Namun laki-laki tetap mendominasi karena perempuan kebanyakan lebih tertarik kepada hal yang berkaitan denga motorik halus seperti seni dan keterampilan. Cabang olahraga yang dominan diminati adalah cabang olahraga sepakbola yakni $29 \%$ karena merupakan cabang olahraga yang digemari oleh seluruh masyarakat Indonesia. Olahraga yang lebih cenderung individu seperti atletik dan pencak silat hampir sama jumlahnya dengan olahraga beregu yakni 25\% dan 23\% dari keseluruhan responden. Mayoritas anggota UKM bidang olahraga UNY sudah berlatih selama lebih dari 2 tahun sehingga memiliki tingkat keterlatihan yang baik. 60\% anggota UKM bidang olahraga UNY memiliki tingkat keterlatihan baik. Tingkat keterlatihan ini, karena mayoritas anggota UKM bidang olahraga UNY merupakan mahasiswa FIK UNY yang merupakan atlet. Atlet yang dapat masuk ke FIK UNY sebagian besar sudah mewakili daerah maupun nasional di cabang olahraga yang ditekuninya.

Prevalensi penanganan DOMS di UKM bidang olahraga UNY menunjukkan bahwa seluruh responden yang mengisi angket pernah mengalami nyeri setelah berlatih. Nyeri yang dirasakan setelah melakukan dapat dikatakan sebagai delayed onset muscle soreness (DOMS). Seluruh responden $100 \%$ pernah mengalami DOMS yang dirasakan setelah melakukan latihan. DOMS merupakan adaptasi tubuh terhadap latihan yang baru dan biasanya muncul di awal latihan/ program latihan baru yang menggunakan kontraksi eccentric. Setengah dari keseluruhan responden (50\%) merasakan nyeri ringan dan $47 \%$ mengalami nyeri sedang setelah melakukan latihan di UKM. Nyeri ringan yang dirasakan oleh mayoritas anggota karena tubuh sudah beradaptasi dengan program latihan yang diberikan pelatih dan latihan yang dilakukan secara rutin.

Penelitian yang dilakukan oleh Cheung et al. 2003 menunjukkan bahwa nyeri yang dirasakan orang coba adalah 24-48 jam setelah melakukan latihan. Nyeri yang dirasakan oleh orang coba pada penelitian tesebut hanyalah nyeri yang bersifat lokal. Data yang diperoleh dari anggota UKM bidang olahraga UNY mayoritas mengalami nyeri setelah 6-12 jam yakni sebanyak 53\% dari keseluruhan responden. Onset DOMS yang dirasakan oleh anggota UKM bidang olahraga UNY lebih cepat dibandingkan dengan penelitian yang sudah dilakukan, hal ini dapat terjadi karena tingkat kebugaran seseorang berbeda-beda. Semakin rendah tingkat kebugaran jasmani seseorang, maka semakin cepat muncul keluhan nyeri setelah beralatih. Nyeri yang dirasakan jarang dialami oleh responden. Sebanyak 85\% responden jarang mengalami nyeri saat DOMS dirasakan. Hal ini disebabkan oleh tubuh yang sudah beradaptasi dengan program latihan yang diberikan. Adaptasi yang dilakukan oleh tubuh berupa superkompensasi yang menyebabkan serabut otot menjadi lebih kuat. Serabut otot yang kuat menjadikan sel satelit cepat dalam meregenerasi sel otot yang rusak.

Meskipun demikian ada beberapa responden yang sangat sering mengalami nyeri yakni sebanyak 5\% responden, hal ini menunjukkan ada sebagian anggota yang lama dalam melakukan adaptasi latihan. Nyeri yang jarang yang dirasakan oleh anggota UKM olahraga UNY dapat disebabkan waktu penulis mengambil data penelitian. Pada saat mengambil data atlet sedang berada pada tahap persiapan yang berbeda ada yang sedang berada dalam tahap persiapan umum, persiapan khusus, persiapan pra-kompetisi, kompetisi, dan transisi. Pada tahap persiapan umum kebanyakan atlet mengalami rasa nyeri karena otot sedang diberikan beban maksimal yang memaksa kontraksi eccentric yang berat. Pada tahap kompetisi atlet akan jarang mengalami rasa nyeri karena beban dan program latihan sudah diturunkan intesitasnya, hal tersebut menunjukkan tahapan latihan mempengaruhi terjadinya DOMS kepada atlet.

Beberapa penanganan terhadap DOMS sudah dilakukan oleh anggota UKM bidang olahraga UNY yaitu stretching, minum obat, kompres es, kompres hangat, masase, istirahat, dan tetap melanjutkan latihan. Mayoritas responden melakukan stretching untuk mengurangi 
rasa nyeri DOMS yakni sebanyak 27 responden (45\%). Berdasarkan penelitian yang dilakukan oleh Javalvand et al. 2016 menunjukkan bahwa kombinasi kedua perlakuan efektif dalam meningkatkan ROM sendi dan mengurangi rasa nyeri saat DOMS. Perlakuan yang diberikan adalah PNF stretching dan pemberian vitamin C pada pre-test dan post-test untuk mengurangi rasa nyeri dan meningkatkan ROM setelah melakukan latihan kekuatan isometrik. Penanganan yang dilakukan oleh mayoritas responden sesuai dengan penanganan para ahli.

Melakukan istirahat dilakukan oleh 25 responden (42\%) untuk menangani DOMS yang dirasakan setelah melakukan latihan. Penanganan dengan istirahat dapat mengurangi bahkan menghilangkan nyeri saat DOMS karena DOMS dapat hilang selama 3 hari bagi rutin melakukan latihan. DOMS yang terjadi hanya terasa selama 24-48 jam setelah melakukan latihan sehingga istirahat dapat mengurangi rasa nyeri pada DOMS. Responden melakukan latihan kembali atau melawan rasa nyeri yang dirasakan, yakni sebanyak 14 responden $(23 \%)$ melakukan latihan kembali. Penelitian yang dilakukan oleh Veqar et al. 2013 menunjukkan bahwa latihan yang dilakukan kembali dapat mengurangi ketegangan yang dirasakan selama mengalami DOMS dan cara yang efektif dalam mengatasi DOMS.

Penanganan yang sering dilakukan oleh responden adalah dengan memberikan kompres es dalam mengurangi rasa nyeri saat mengalami DOMS yaknis sebanyak 11 responden (18\%). Penanganan dengan kompres hangat juga dilakukan oleh 6 responden (10\%). Penanganan dengan kompres dingin dan kompres hangat sesuai dengan penelitian Sellwood et al. 2013 yang menyatakan pemberian air panas dengan suhu 380 Celcius lebih efektif mengurangi DOMS dibandingkan pemberian air dingin dengan suhu 200 Celcius selama 30 menit. Namun pada penelitian Machado et al. 2013 menyatakan pemberian air dingin selama 11-15 menit efektif mengurangi rasa nyeri dibandingkan istirahat pasif.

Pemberian masase atau pijat juga dilakukan oleh responden dalam menangani DOMS yakni sebanyak 9 responden $(15 \%)$ memilih masase dalam menangani DOMS. Masase merupakan metode yang sudah lama dilakukan untuk mengurangi rasa nyeri karena berlatih. Pemberian masase ringan pada jaringan otot dapat mengurangi mikrotruma yang dirasakan oleh otot setelah berlatih (Vegar et al. 2013). Penanganan yang telah dilakukan oleh mayoritas anggota dapat efektif dalam mengurangi rasa nyeri yang dirasakan selama mengalami DOMS. Sebanyak 51 responden (85\%) menyatakan efektif dengan penanganan yang selama ini telah dilakukan.

Lokasi nyeri yang dirasakan oleh anggota UKM bidang olahraga UNY dapat dirasakan pada beberapa otot besar. Pada Tabel 5 menunjukkan lokasi nyeri yang dialami saat mengalami DOMS. Mayoritas responden mengalami nyeri pada bagian otot betis (gastrocnemius) yakni sebanyak 32 responden (53\%). Otot ini menopang seluruh gerakan manusia yang menggunakan tungkai. Pada otot ini juga sering terjadi timbunan asam laktat pada aktivitas berat. Lokasi nyeri yang kedua pada otot hamstring yakni sebanyak 25 responden (42\%). Otot hamstring juga berada diatas otot betis sehingga juga mengalami nyeri saat terjadi DOMS. Bagian otot yang nyeri disebabkan latihan yang menggunakan kontraksi otot eccentric yang memaksa otot untuk memanjang selama melakukan aktivitas. Pada penelitian yang sudah dilakukan juga diketahui otot yang sering digunakan (otot dominan) merupakan otot yang sering mengalami nyeri DOMS. Beberapa cabang olahraga dominan otot yang mengalami nyeri terdapat pada otot betis dan hamstring. Meskipun terdiri dari beberapa cabang olahraga dengan dominan bagian tubuh yang digunakan berbeda tetapi mayoritas responden mengalami nyeri pada otot betis dan hamstring.

Kesamaan lokasi nyeri pada setiap cabang olahraga dapat disebabkan oleh banyaknya aktivitas yang dominan menggunakan tungkai. Jenis latihan yang dilakukan berpengaruh terhadap lokasi nyeri yang dirasakan. Durasi yang dirasakan selama mengalami DOMS mayoritas responden hanya selama 1 hari (24 jam) yakni sebanyak $40 \%$ dari responden. Nyeri yang dirasakan hanya sementara karena sudah dilakukan beberapa penanganan dan besar nyeri 
yang dirasakan hanya nyeri yang ringan. Latihan yang dominan menggunakan salah satu bagian tubuh yang menyebabkan nyeri, maka nyeri yang terjadi pada bagian tubuh tersebut dapat hilang sendiri selama 1 hari dengan penanganan yang sesuai.

Gejala yang dirasakan selain nyeri saat mengalami DOMS anggota UKM bidang olahraga UNY adalah kaku otot, bengkak, nyeri tekan, hangat, nyeri gerak, dan panas. Sebanyak 28 responden (47\%) mengalami kaku otot selama mengalami DOMS dan 20 responden (33\%) mengalami nyeri gerak. Gejala yang dirasakan oleh responden merupakan akibat yang dirasakan selama mengalami DOMS selain nyeri. Kaku otot dan nyeri gerak yang dirasakan dapat disebabkan karena kurang pemanasan dan juga gerakan pada bagian yang dominan saat beraktivitas olahraga. Selain itu jenis latihan yang dilakukan dapat memicu gejala yang dirasakan selain nyeri.

Jenis latihan beban banyak memicu DOMS mayoritas anggota UKM bidang olahraga UNY. Sebanyak 45\% responden mengalami DOMS karena dipicu oleh latihan beban. Pada penelitian yang telah dilakukan (Cheung et al. 2003) menunjukkan kontraksi eccentric paling banyak memicu DOMS karena kontraksi otot harus memanjang dan memendek dengan kuat sehingga banyak asam laktat yang terbentuk. Latihan beban yang dilakukan merupakan salah satau penyebab timbulnya DOMS. Latihan yang paling banyak memicu DOMS selanjutnya adalah lari jauh dan lari cepat dengan jumlah yang sama yaitu 13 responden (22\%). Latihan ini dapat memicu karena menggunakan dominan sistem energi yang dapat membentuk timbunan asam laktat. Sistem energi yang digunakan meliputi sistem energi aerobik dan sistem energi anaerobik. Kecenderungan sistem energi anaerobik dapat membentuk asam laktat yang cepat dan memicu timbulnya DOMS. Sistem energi aerobik lebih cenderung pada durasi yang lama sehingga membuat kondisi otot kelelahan dan memicu terjdainya DOMS.

Hasil penelitian ini dapat disimpulkan semua anggota UKM bidang olahraga UNY pernah mengalami DOMS setalah melakukan latihan. Seluruh responden melakukan penanganan yang sudah sesuai dengan penelitian yang sudah dilakukan. Lokasi DOMS terletak pada bagian yang dominan digunakan saat beraktivitas pada suatu cabang olahraga. DOMS yang dirasakan memiliki beberapa gejala yang dirasakan saat mengalami DOMS selain nyeri. Aktivitas olahraga yang menggunakan kontraksi eccentric sering memicu DOMS.

\section{SIMPULAN}

Berdasarkan hasil analisis dan pembahasan pada bab sebelumnya maka dapat diambil kesimpulan sebagai berikut: Kesimpulan penelitian ini, bahwa semua anggota UKM olahraga UNY pernah mengalami DOMS meskipun jarang dirasakan setelah melakukan latihan. Nyeri yang dirasakan disebabkan oleh program latihan baru (awal latihan) yang menggunakan kontraksi eccentric. DOMS paling sering dirasakan 6-12 jam setelah melakukan latihan dengan durasi nyeri selama 1 hari. Lokasi DOMS yang dirasakan mayoritas terjadi pada otot betis (gastrocnemius). DOMS yang dirasakan mayoritas subyek dalam kategori ringan. Tanda gejala DOMS yang dirasakan selain nyeri adalah kaku otot \& nyeri untuk bergerak. Jenis latihan yang memicu DOMS yang utama adalah latihan beban. Penanganan yang banyak dilakukan responden untuk mengatasi DOMS adalah melakukan stretching \& istirahat. Penanganan yang dilakukan sudah efektif dalam mengurangi rasa nyeri yang dirasakan mayoritas subyek.

Berdasarkan kesimpulan penelitian, saran relevan yang dapat diberikan adalah sebagai berikut: dalam melakukan penanganan yang benar dan efektif dalam mengurangi rasa nyeri selama mengalami DOMS. Penanganan yang benar dapat membantu atlet dalam meraih prestasi dan mencapai tujuan latihan yang diberikan oleh pelatih. Pelatih hendaknya dapat memberikan program latihan yang membantu dalam mengurangi dan mencegah terjadinya DOMS setelah melakukan latihan agar program latihan yang selanjutnya dapat berjalan dengan maksimal. Pelatih dapat memberikan program latihan untuk menghindari terjadinya DOMS. Pelatih dapat melakukan upaya penanganan terhadap DOMS yang dirasakan oleh atlet agar 
program latihan dapat berjalan dengan baik. Seorang pelatih ataupun tim medis, hendaknya juga memberikan penanganan yang benar dan efektif saat DOMS dialami oleh anggotanya. Penanganan yang benar dan efektif dapat membantu pelatih dalam memberikan program latihan sehingga sasaran program latihan dapat tercapai sesuai dengan target yang akan dicapai. UKM dapat memfasilitasi dalam proses penanganan DOMS yang dialami oleh anggota.

\section{DAFTAR PUSTAKA}

Cheung, K., Hume, P.A., \& Maxwelh, L. (2003). Delayed Onset Muscle Soreness: Treatent Strategies and Performance Factors. [Versi elektronik]. ResearchGate, 33, 145-164.

Contro, V., Mancuso, P.E., \& Proia, P. (2016). Delayed Onset Muscle Soreness (DOMS) Management: Present State of the Art. Trends In Sport Scieces, 3, 121-127.

Day, M., \& Ploen, E. (2010). The Effetiveness of Cryotherapy in the Treatment of ExerciseInduced Muscle Soreness. UW-L Journal of Undergraduate Research, 13, 1-6.

Declan, A.J, Sayers, C.S., \& McHugh, M.P. (2003). Treatment and Prevention Delayed Onset Muscle Soreness. Journal of Strength and Conditioning Research, 17, 197-208.

Soreness (DOMS). International Journal of Biological \& Medical Research, 3, 1469-1475.

Sugiyono. (2010). Metode Penelitian Administrasi. Bandung: Alfabeta.

Suharjana. (2013). Kebugaran jasmani. Yogyakarta: Jogja Global Media

Veqar, Z. (2013). Causes and Management of Delayed Onset Muscle Soreness: A Review. Human Phisiology, 55, 13205-13211.

Weerapong, P. (2005). Preexercise Strategies: The Effects of Warm-Up, Stretching, and Massage Symptoms of Eccentric Exercise-Induced Muscle Damage and Performance. Tesis master, tidak diterbitkan, Auckland University of Technology, New Zealand. 